\title{
Article \\ Rheum rhaponticum Root Extract Improves Vasomotor Menopausal Symptoms and Estrogen-Regulated Targets in Ovariectomized Rat Model
}

\author{
Mickey Wilson ${ }^{1,2}$, Veera Konda ${ }^{3}$, Kathryn Heidt ${ }^{1,4}$, Thirumurugan Rathinasabapathy ${ }^{1,2}$, Anuradha Desai ${ }^{3}$ and \\ Slavko Komarnytsky ${ }^{1,2, * \mathbb{D}}$
}

1 Plants for Human Health Institute, North Carolina Research Campus, North Carolina State University, 600 Laureate Way, Kannapolis, NC 28081, USA; mlwilso8@ncsu.edu (M.W.); ksheidt@catawba.edu (K.H.); trathin@ncsu.edu (T.R.)

2 Department of Food, Bioprocessing \& Nutrition Sciences, North Carolina State University, 400 Dan Allen Drive, Raleigh, NC 27695, USA

3 Metagenics Inc., 9770 44th Ave NW, Gig Harbor, WA 98332, USA; veerakonda@gmail.com (V.K.); AnuDesai@metagenics.com (A.D.)

4 Department of Biology, Catawba College, 2300 W Innes Street, Salisbury, NC 28144, USA

* Correspondence: komarnytsky@ncsu.edu; Tel.: +1-704-250-5459

Citation: Wilson, M.; Konda, V.; Heidt, K.; Rathinasabapathy, T.; Desai, A.; Komarnytsky, S. Rheum rhaponticum Root Extract Improves Vasomotor Menopausal Symptoms and Estrogen-Regulated Targets in Ovariectomized Rat Model. Int. J. Mol. Sci. 2021, 22, 1032. https:// doi.org/10.3390/ijms22031032

Academic Editor: Raffaele Capasso

Received: 15 December 2020

Accepted: 14 January 2021

Published: 21 January 2021

Publisher's Note: MDPI stays neutra with regard to jurisdictional claims in published maps and institutional affiliations.

Copyright: (C) 2021 by the authors. Licensee MDPI, Basel, Switzerland. This article is an open access article distributed under the terms and conditions of the Creative Commons Attribution (CC BY) license (https:/ / creativecommons.org/licenses/by/ $4.0 /)$.

\begin{abstract}
Ovarian insufficiency and ovariectomy are characterized by deregulated heat loss mechanisms. Unlike hormone therapy, ERr 731 (a standardized botanical extract of Siberian rhubarb Rheum rhaponticum L. high in rhaponticin) acts like a selective estrogen receptor modulator for ER $\beta$ receptors and may offer a higher degree of safety while maintaining the desired efficacy profile. In this study, we examined the relationship between oral administration of ERr 731 and the underlying components of skin vasomotion responses in an ovariectomized (OVX) rat model. ERr 731 dosedependently reduced tail skin temperature $\left(\mathrm{T}_{\text {skin }}\right)$ values by an average of $1{ }^{\circ} \mathrm{C}$. The rapid onset of this effect was observed in 1 and $3 \mathrm{mg} / \mathrm{kg} /$ day ERr 731 groups as early as day 2 of administration, and remained in place for the duration of the treatment ( 2 weeks). Substituting ERr 731 after $E_{2}$ withdrawal helped maintain body temperature similarly to $E_{2}$ alone, suggesting the usefulness of ERr 731 for replacing existing hormonal therapy in humans. ERr 731 also acted as a highly selective agonist for ER $\beta$ in the hypothalamus of OVX rats, as well as in ER $\alpha / \beta$ cell-based reporter assays. These data validate the OVX/ $\mathrm{T}_{\text {skin }}$ rat model as a suitable screening platform to evaluate botanical and pharmaceutical treatments of menopause, while providing further evidence for the efficacy of ERr 731 towards alleviating vasomotor menopausal symptoms and improving wellbeing during the menopausal transition.
\end{abstract}

Keywords: postmenopausal; estrogens; hot flashes; HRT; ERr 731

\section{Introduction}

An estimated 6000 American women transition to menopause every day, with $75 \%$ of women aged 50 to 55 years old assumed to be postmenopausal [1]. Among the eleven key health issues selected in terms of burden exerted in women's mortality, morbidity, disability and quality of life, vasomotor symptoms play a prominent role [2]. To date, the most effective and reliable therapy for menopausal vasomotor symptoms (e.g., hot flushes, night sweats) is hormone replacement therapy (HRT). However, long-term HRT carries the increased risk of hormone-related cancers and cardiovascular disease [3]. Mood modulators and selective serotonin re-uptake inhibitors are commonly recommended for short-term use in highly symptomatic women who are not HRT candidates, but these treatments lack supported data on safety and efficacy [4]. Natural approaches for hot flush relief aim to reduce the daily vasomotor symptoms (frequency, intensity, and number) and improve quality of life through supplementation with phytoestrogens (soy, red clover, flax, 
hops, hesperidin, and kudzu) and non-phytoestrogens, i.e., black cohosh, essential fatty acids, vitamin E, and succinates [5]. Unlike HRT, these approaches may specifically target specific estrogen receptors (ER) and therefore offer more selective clinical benefits [6].

Rhapontic rhubarb roots (Rheum rhaponticum L., family Polygonaceae) contain a significant amount of hydroxystilbene compounds without any anthraquinones [7]. The standardized ERr 731 extract contains rhaponticin and desoxyrhaponticin glycosides as the main bioactive constituents (Figure 1), in addition to lesser amounts of their respective rhapontigenin and desoxyrhapontigenin aglycones ( $5 \%)$ [8]. The ERr 731 extract, as well as its individual compounds, have been demonstrated to act as potent, selective ER $\beta$ agonists in human endometrial cells, without significant ER $\alpha$ effects [9]. The safety of ERr 731 was evaluated in 90-day rat [10] and 13-week dog [11] studies. Subsequent clinical investigations suggested that ERr 731 was well tolerated in the long-term observational studies $[7,12]$. ERr 731 was effective in decreasing the number and severity of hot flushes in a 12-week multicenter trial that included 109 women with climacteric complaints [7], a menopause rating scale total score given after 6 months of treatment in 252 women [13], as well as 112 perimenopausal women with menopausal symptoms followed for 12 weeks [14]. Postmarketing surveillance data from Germany (140 million daily doses), the United States and Canada (13 million) suggest that the extract is generally safe for consumption [15]. However, it is not clear how effective ERr 731 supplementation is following the substitution after termination of HRT ( $E_{2}$ withdrawal).

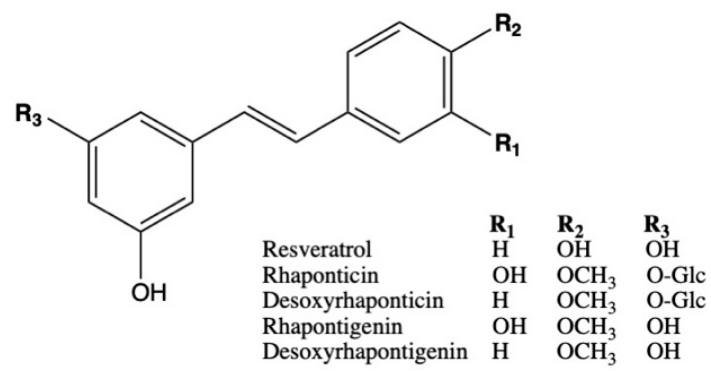

Figure 1. Schematic representation of bioactive constituents from the ERr 731 rhubarb root extract in comparison to their respective glycosides and trans-resveratrol.

In rats, vasodilation of the tail is a primary heat-dissipating mechanism [16] that can be monitored by measuring tail skin temperature $\mathrm{T}_{\text {skin }}$ [17]. $\mathrm{T}_{\text {skin }}$ is increased by ovariectomy $(\mathrm{OVX})$ and reduced by administration of $17 \beta$-estradiol $\left(\mathrm{E}_{2}\right)$, thus making the OVX rat model combined with an inexpensive, non-invasive $T_{\text {skin }}$ monitoring device attached in a protective covering on the surface of the tail a versatile screening platform to evaluate botanical and pharmaceutical treatments of hot flushes and general wellbeing during menopause [18]. Because hot flushes correlate to a spiking of the peripheral LH and GnRH released from the hypothalamus, they most likely represent a disorder of hypothalamic thermoregulation [19].

The present study was designed to examine the acute and replacement therapy effects of ERr 731 supplementation on several underlying components of skin vasomotion responses in the OVX rat model, and to substantiate these changes with the hypothalamic expression patterns of genes related to the $E R \alpha / \beta$ signaling and bioactive peptides.

\section{Results}

\subsection{ERr 731 and $E_{2}$ Treatments Lower $T_{\text {skin }}$ in OVX Rat Model}

All treatment groups displayed circadian rhythms of $\mathrm{T}_{\text {skin }}$ with multiple spontaneous fluctuations. OVX animals showed a clear increase in $\mathrm{T}_{\text {skin }}$ over the respective Sham controls during both the dark (active) and light (inactive) phases of the day (Figure 2A). $\mathrm{E}_{2}$ treatment $(0.1 \mathrm{mg} / \mathrm{kg} /$ day $)$ of OVX rats resulted in decreased $\mathrm{T}_{\text {skin }}$ that was evident on day 1 and reached significance by the dark phase of day 2 (Figure 2B). ERr 731 treatment at $1 \mathrm{mg} / \mathrm{kg} /$ day produced a mild suppression of $T_{\text {skin }}$ during the dark phase that was only significantly different from OVX rats on a few occasions, starting on day 2 (Figure 2C,D). 


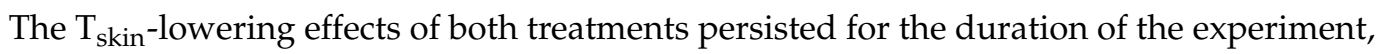
as was evident on day 7 of the treatment (Figure 3A,D).

A

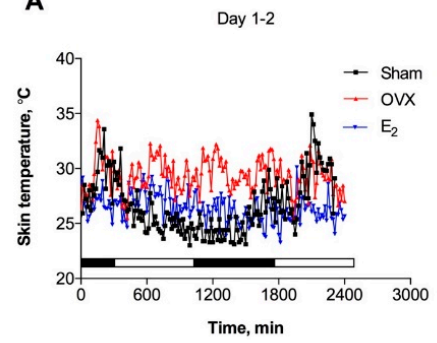

C

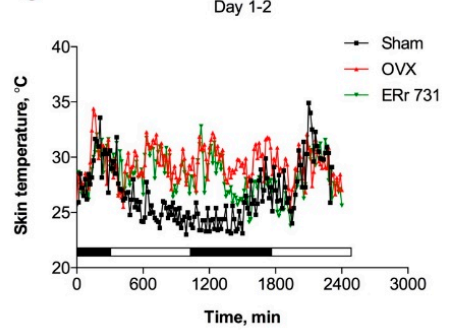

B

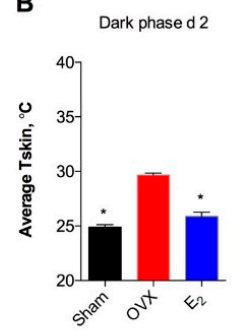

D

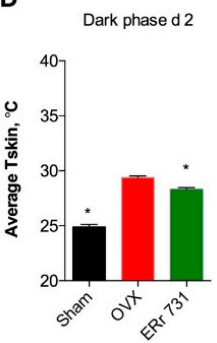

Figure 2. Effects of $\mathrm{ERr} 731$ and $17 \beta$-estradiol $\left(\mathrm{E}_{2}\right)$ on tail skin temperature $\left(\mathrm{T}_{\text {skin }}\right)$ in ovariectomized (OVX) rat model after 2 days of treatment. (A) Recordings of OVX controls (red) show circadian rhythm and increased $\mathrm{T}_{\text {skin }}$ as compared to intact (Sham, black) animals, while $\mathrm{E}_{2}$ treatment (blue) is associated with decreased $\mathrm{T}_{\text {skin }}$ on days 1-2; (B) Average $\mathrm{T}_{\text {skin }}$ is significantly increased in OVX rats and is reduced following $\mathrm{E}_{2}$ treatment in the dark phase of day 2; (C) Recordings of decreased $\mathrm{T}_{\text {skin }}$ following ERr 731 treatment (green) on days 1-2; (D) Average $T_{\text {skin }}$ is significantly reduced in ERr 731-treated rats in the dark phase of day 2. Data are the mean $\pm \operatorname{SEM}(n=6),{ }^{*} p<0.05$ vs. OVX control.

A
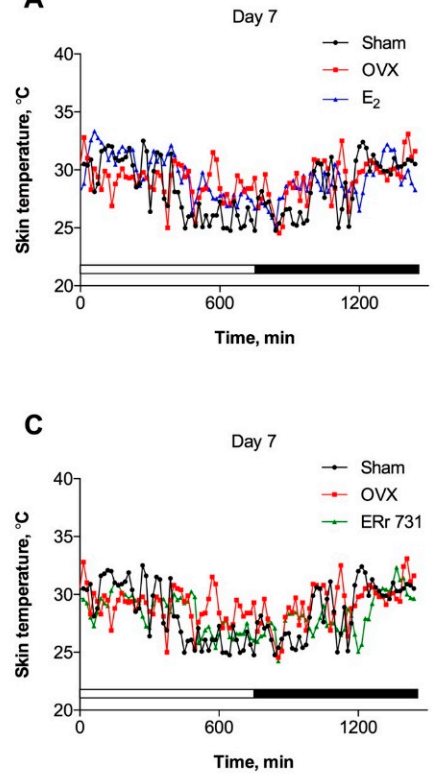

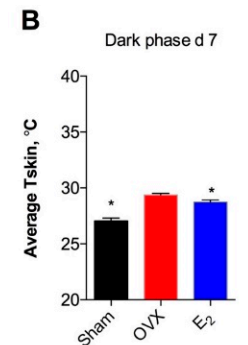

D

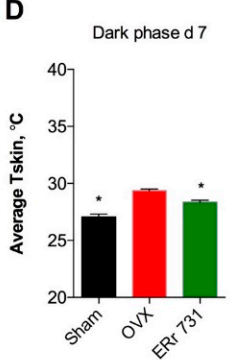

Figure 3. Effects of ERr 731 and $E_{2}$ on $T_{\text {skin }}$ persisted for one week of treatment. (A) Recordings of OVX controls (red) show circadian rhythm and increased $\mathrm{T}_{\text {skin }}$ as compared to intact (Sham, black) animals, while $\mathrm{E}_{2}$ treatment (blue) is associated with decreased $\mathrm{T}_{\text {skin }}$ on day 7; (B) Average $\mathrm{T}_{\text {skin }}$ is significantly increased in OVX rats and reduced following $\mathrm{E}_{2}$ treatment in the dark phase of day 7; (C) Recordings of decreased $\mathrm{T}_{\text {skin }}$ following ERr 731 treatment (green) on day 7; (D) Average $\mathrm{T}_{\text {skin }}$ is significantly reduced in ERr 731-treated rats in the dark phase of day 7. Data are the mean $\pm \mathrm{SEM}$ $(n=6), * p<0.05$ vs. OVX control. 


\subsection{Dose-Dependent Effects of ERr 731 Treatment}

The dose response effects of ERr 731 on $\mathrm{T}_{\text {skin }}$ were evident in the dark phase of days 2,7 and 14 of the dose ranging study. $E_{2}$ treatment $(0.1 \mathrm{mg} / \mathrm{kg} /$ day $)$ was significantly effective in reducing $\mathrm{T}_{\text {skin }}$ on days 2 and 14, but did not reach significance on day 7 . ERr 731 administered at doses of 1 and $3 \mathrm{mg} / \mathrm{kg} /$ day lowered $\mathrm{T}_{\text {skin }}$ similar to $\mathrm{E}_{2}$. A lower dose of the ERr 731 extract $\left(0.3 \mathrm{mg} / \mathrm{kg} /\right.$ day) did not have a significant effect on $\mathrm{T}_{\text {skin }}$ over the 14-day treatment period (Figure $4 \mathrm{~A}-\mathrm{C}$ ).
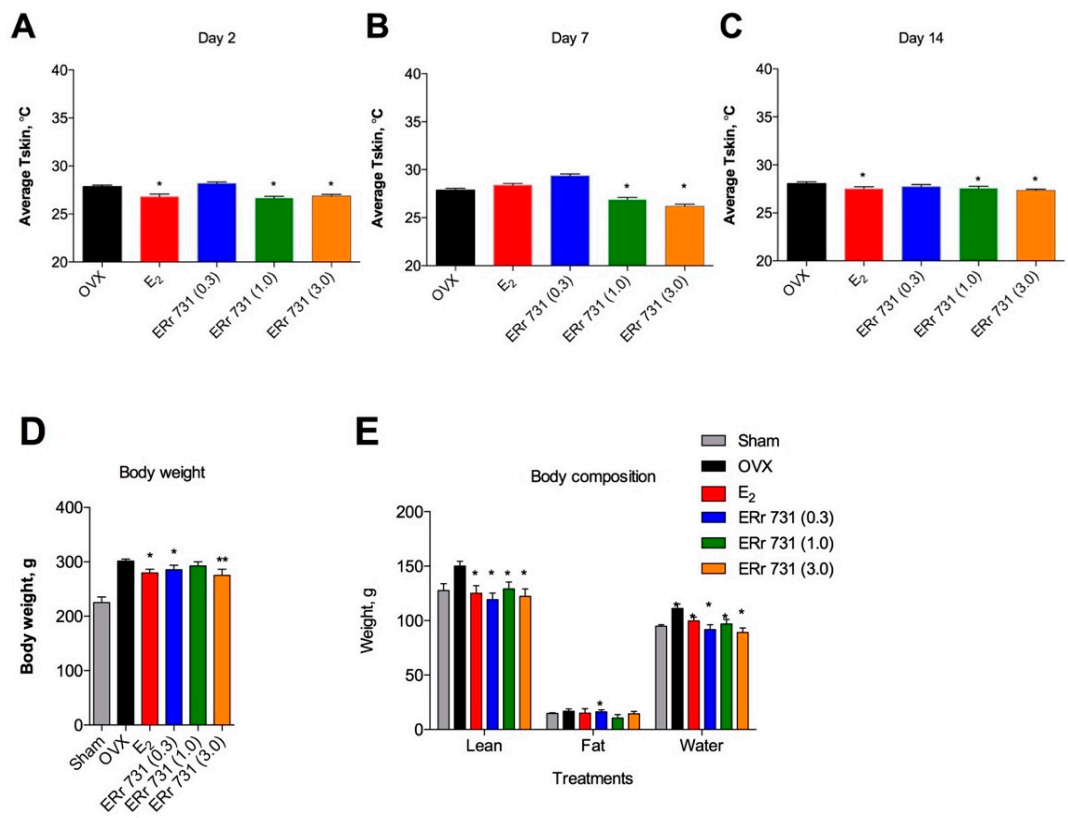

Figure 4. Dose-dependent effects of ERr 731. Average $\mathrm{T}_{\text {skin }}$ was significantly increased in OVX rats and was reduced following $E_{2}(0.1 \mathrm{mg} / \mathrm{kg} /$ day $)$ or ERr $731(0.3 \mathrm{mg} / \mathrm{kg} / \mathrm{day}, 1 \mathrm{mg} / \mathrm{kg} /$ day, and 3 $\mathrm{mg} / \mathrm{kg} /$ day) oral supplementation for two weeks in the dark phase of (A) day 2, (B) day 7, and (C) day 14 of the study. (D) Compared with Sham animals, the average body weight was significantly increased in OVX rats and decreased in $\mathrm{E}_{2}$ - and ERr 731-treated animals. (E) Body composition measurements indicated an equal reduction in lean fat mass and total body water in all treatments with the exception of animals receiving $1 \mathrm{mg} / \mathrm{kg} /$ day ERr 731, which showed a significant decrease in fat mass associated with the treatment. Data are the mean $\pm \operatorname{SEM}(n=6),{ }^{*} p<0.05,{ }^{* *} p<0.01$ vs. OVX control.

OVX surgery resulted in a significant body weight gain as compared to Shams, and this effect was partially reversed by $E_{2}$ treatment and the highest dose of the ERr 731 extract. A similar, but non-significant, trend was observed with lower doses of the ERr 731 extract as well (Figure 4D). Body composition measurements showed that the observed decrease in total body weight was due to an equal reduction of lean fat mass and total body water. A significant decrease in fat mass was observed in animals receiving $1 \mathrm{mg} / \mathrm{kg} /$ day ERr 731, but this effect was not dose-dependent (Figure 4E).

\subsection{Replacement Effects of ERr 731 in OVX Rats Receiving $E_{2}$}

In modeling the ERr 731 replacement strategy, 24 animals in study 3 received daily gavage with vehicle during the initial phase of the study (black bar, days 1-7) for one week, to establish baseline $T_{\text {skin }}$ averages. Next, animals were randomized into oral $E_{2}$ supplementation (red bar, $0.3 \mathrm{mg} / \mathrm{kg} /$ day for days $8-14, n=18$ ) to achieve significant reductions in $\mathrm{T}_{\text {skin }}$ values. Finally, two groups of $\mathrm{E}_{2}$ rats were randomized to replace the existing $E_{2}$ supplementation with 1 or $3 \mathrm{mg} / \mathrm{kg} /$ day ERr 731 supplementation (green bar, days 15-21) for the duration of the study. $T_{\text {skin }}$ values remained stable in all animals receiving daily gavage with vehicle during the initial phase. The $E_{2}$ treatment of OVX rats significantly reduced $\mathrm{T}_{\text {skin }}$ similarly to levels observed in animal studies 1 and 2. ERr 731 
replacement therapy at doses of 1 and $3 \mathrm{mg} / \mathrm{kg} /$ day lowered $\mathrm{T}_{\text {skin }}$ similarly to $\mathrm{E}_{2}$, although some $\mathrm{T}_{\text {skin }}$ value rebound was observed at the lower dose tested (Figure 5).

A
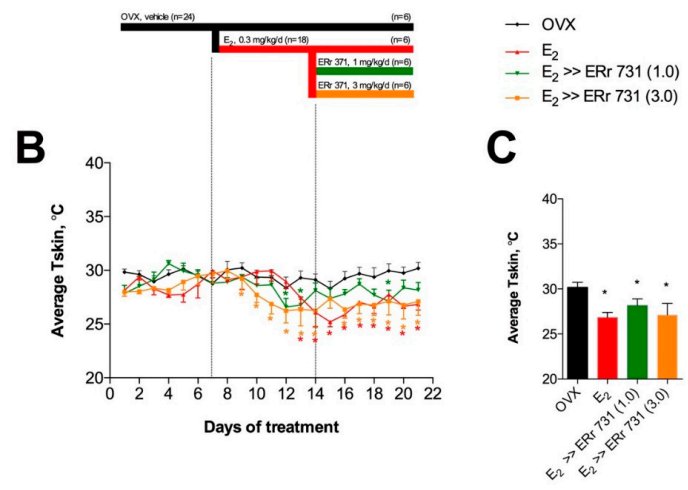

Figure 5. Time course of $E_{2}$ supplementation and ERr 731 replacement therapy in OVX rats. (A) Schematic diagram of the replacement strategy. (B) In the dark phase, the $E_{2}$ treatment of OVX rats significantly reduced $T_{\text {skin }}$ from experimental day 10 (day 2 of $E_{2}$ treatment) through the end of the study. In rats that received ERr 731 therapy, the effect remained significant at high doses ( $3 \mathrm{mg} / \mathrm{kg} /$ day) and reached significance on several days at middle dose $(1 \mathrm{mg} / \mathrm{kg} /$ day) through the end of the study. (C) Overall average $\mathrm{T}_{\text {skin }}$ was significantly increased in OVX rats and reduced following either $E_{2}(0.3 \mathrm{mg} / \mathrm{kg} /$ day $)$ or ERr 731 replacement therapy $(1-3 \mathrm{mg} / \mathrm{kg} /$ day) for the duration of the treatment. Data are the mean $\pm \operatorname{SEM}(n=6),{ }^{*} p<0.05$ vs. OVX control.

\subsection{Plasma Levels of Rhubarb Extract Bioactives}

Rhaponticin aglycone was detected in the plasma of animals receiving 1 or $3 \mathrm{mg} / \mathrm{kg} /$ day ERr 731 botanical extract in the range of $45-130 \mathrm{ng} / \mathrm{mL}$ (animal study 2) and $44-114 \mathrm{ng} / \mathrm{mL}$ (animal study 3), thus confirming its intestinal absorption and bioavailability (Figure 6A,B).
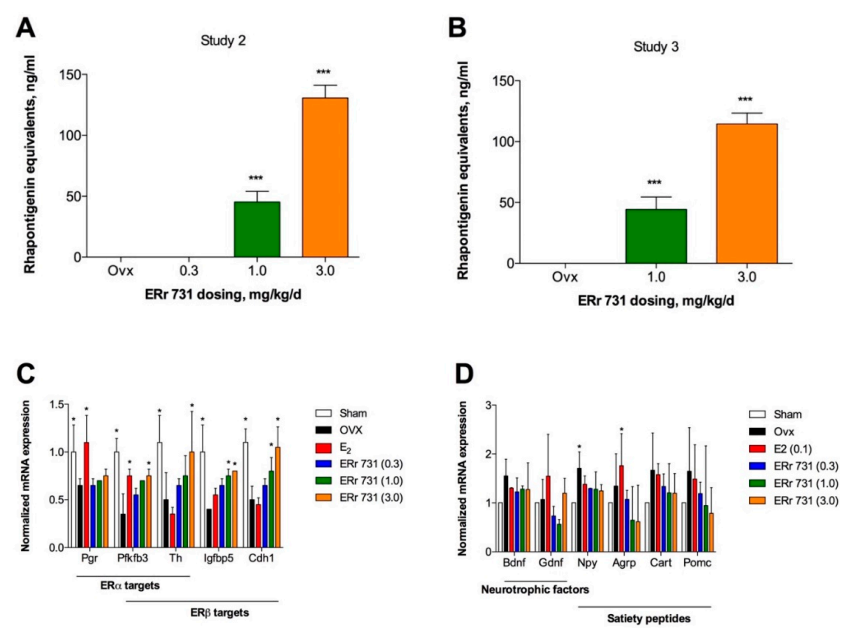

Figure 6. Plasma concentration of ERr 731 metabolite and the pharmacogenomic profiles for ER $\alpha / \beta$ target genes and bioactive peptides in the hypothalamus of ERr 731-treated rats. (A) Rhaponticin metabolite was detected in the plasma of rats treated orally with $0.3-3 \mathrm{mg} / \mathrm{kg} /$ day ERr 731 for 14 days in study 2 and (B) 7 days in study 3. (C) $E_{2}$ treatment significantly upregulated ER $\alpha$ but not ER $\beta$ target genes in the hypothalamus of OVX rats, and the opposite effect was observed for ERr 731. (D) Neither $E_{2}$ nor ERr 731 modulated the expression of neurotrophic factors; however, an agouti-related peptide Agrp was significantly elevated following the OVX surgery and ERr 731 treatment abolished this response. Individual hypothalamic tissue samples $(n=6)$ were analyzed by fluorescent quenching (A,B) or qPCR $(\mathbf{C}, \mathbf{D})$, and the data were expressed as the mean \pm SEM, ${ }^{*} p<0.05$ and ${ }^{* * *} p<0.001$ vs. OVX control. 


\subsection{Hypothalamic Gene Expression Profiles for ER $\alpha / \beta$ Target Genes and Peptides}

$\mathrm{ER} \alpha / \beta$ targets were selected based on a prior global identification of estrogen receptor target genes and signaling networks [19], as well as common neurotrophic factors ( $B d n f$, Gdnf) and satiety peptides (Npy, Agrp, Cart, Pomc) [20]. Remarkably, $\mathrm{E}_{2}$ treatment significantly upregulated the expression of progesterone receptor (Pgr), an ER $\alpha$ target gene, and this response was absent in the ERr 731-treated animals. Two putative ER $\beta$ target genes (Igfbp5 and Cdh1) showed a significant, dose-dependent response to $\mathrm{ERr} 731$, but not $\mathrm{E}_{2}$ treatments (Figure 6C). Neither $\mathrm{E}_{2}$ nor ERr 731 modulated the expression of neurotrophic factors in the hypothalamus (Figure 6D). Among the satiety peptides tested, agouti-related peptide Agrp was significantly elevated following the OVX surgery and ERr 731 (but not $E_{2}$ ) treatment abolished this response (Figure $6 \mathrm{D}$ ).

\subsection{ERr 731 Shows a Selective ER $\beta$ Agonist Activity In Vitro}

$\mathrm{ERr} 731$ had little effect on $\mathrm{ER} \alpha$, causing a less than 3-fold increase over the maximum reported activity (Figure 7A), but strongly activated ER $\beta$ to a 36-fold increase over the maximum reported activity (Figure 7B). Similar to genistein and (S)-equol, ERr 731 and its major bioactive aglycone, rhapontigenin, acted as full ER $\beta$ agonists (Figure $7 \mathrm{C}, \mathrm{D}$ ). Overall, ERr 731 showed a 13.5-fold difference in ER $\beta / E R \alpha$ specificity when compared to $E_{2}$ at a maximum receptor activation value. The specificities for the other known estrogenic compounds were much smaller, in the range of 0.31 for $E_{2}, 0.37$ for equol, 0.3 for genistein, and 3.2 for quercetin.

A

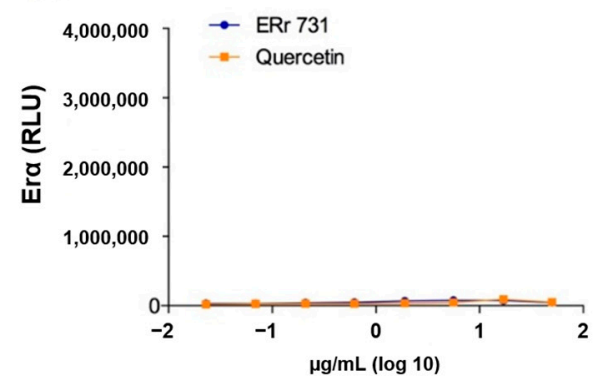

C

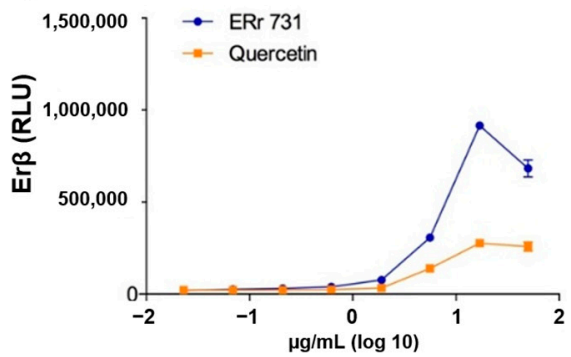

B

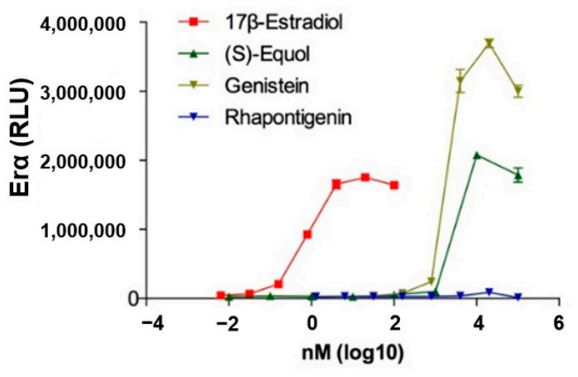

D

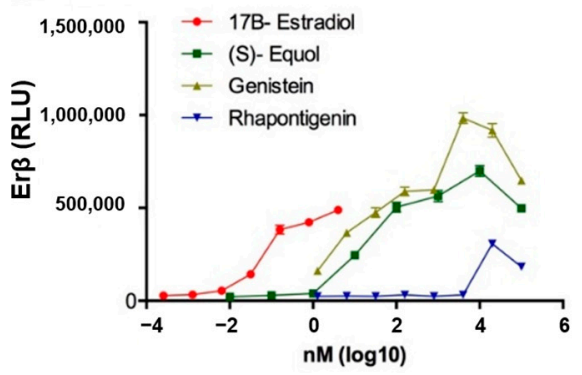

Figure 7. Induction of ER- $\alpha(\mathbf{A}, \mathbf{B})$ activity versus ER- $\beta$ activity (C,D) from ERr 731 extract as compared to quercetin, estradiol, equol, genistein and rhapontigenin. ER $\alpha$ or ER $\beta$ reporter cells were treated in triplicate wells with various concentrations of test compounds for $24 \mathrm{~h}$, and ER receptor activity was quantified as relative luminescence units (RLU). Agonist concentrations were transformed to $\log 10 \mu \mathrm{g} / \mathrm{mL}$ for botanical extracts or $\log 10 \mathrm{nM}$ for single compounds. Each data point represents mean $\pm \mathrm{SD}$.

\section{Discussion}

The top eleven major health issues present in peri- and postmenopausal women are vasomotor symptoms, depression, dementia, sleep disorders, migraine, cardiovascular disease, metabolic syndrome, diabetes, chronic respiratory syndrome, cancer and muscu- 
loskeletal diseases [2]. Vasomotor symptoms are tightly linked with hormonal loss and the quality of life is severely affected. Since there is a large placebo effect in humans, and the majority of the tested natural compounds showed an inconsistent result in clinical studies for the alleviation of vasomotor symptoms [5], there is a critical need for the development of proper screening methods that predict the efficacy of such therapeutic intervention in humans.

In this study, we used a noninvasive method for measuring $\mathrm{T}_{\text {skin }}$ with SubCue Mini data loggers in a modified protective casing, attached to the surface of the rat tail [17]. Because $\mathrm{T}_{\text {skin }}$ increase highly correlates with the occurrence of hot flushes, it has been commonly used as one of the phenotypical (objective) markers for menopause symptoms [21]. In OVX rats, vasodilation ( $\mathrm{T}_{\text {skin }}$ increase) starts at a significantly lower core temperature than in Sham rats [22]. This is a strong indication that OVX rats are more prone to undergo induction of vasodilatory heat dissipation, and therefore provide a good model for studying menopausal hot flashes [23]. This technology is readily accessible to most laboratories and, in our opinion, represents a highly suitable screening platform to evaluate dietary, botanical, or pharmaceutical interventions for their ability to modulate the mechanisms and treatments of menopause.

Our experimental findings provide further evidence for the efficacy of a rhubarb root extract ERr 731 in improving vasomotor menopausal symptoms, and raise the intriguing possibility that it is effective in improving wellbeing during the menopausal transition. $\mathrm{E}_{2}$ treatment $(0.1 \mathrm{mg} / \mathrm{kg} /$ day $)$ of OVX rats resulted in decreased $\mathrm{T}_{\text {skin, }}$, which was evident on day 1 and reached significance by the dark phase of day 2, similar to the previously published studies [18]. In a dose ranging study, ERr 731 botanical extract administered at low $(0.3 \mathrm{mg} / \mathrm{kg} /$ day $)$, middle $(1 \mathrm{mg} / \mathrm{kg} /$ day $)$, or high $(3 \mathrm{mg} / \mathrm{kg} /$ day $)$ doses reduced the $\mathrm{T}_{\text {skin }}$ values of OVX rats by an average of $1{ }^{\circ} \mathrm{C}$. The human equivalent dose for the middle dose used in this study was estimated at $0.16 \mathrm{mg} / \mathrm{kg} /$ day or $10 \mathrm{mg} /$ day of ERr 731 extract for an average adult [24]. This is in line with previous uses of ERr 731 in humans to alleviate the symptoms of menopause. The ERr 731 group receiving $4 \mathrm{mg} /$ day of the botanical extract showed significant improvements in 11 common menopausal complaints during a 12-week randomized, double-blind clinical study [7]. In a 6-month observational study, ERr 731 taken at 4 or $8 \mathrm{mg} /$ day resulted in a significant decrease in the menopause rating scale total score, from 14.5 points at baseline to 6.5 points [13]. This compares favorably to the dosing of soy isoflavones (30-90 mg/day) [25], red clover isoflavones (40-120 mg/day) [26] or black cohosh triterpene glycosides (10-60 mg/day) [27], to achieve similar beneficial results.

The present study was also designed to examine ERr 731 supplementation after hormone replacement therapy (HRT) withdrawal or the discontinuation of $\mathrm{E}_{2}$ treatment. ERr731 supplementation at 1 and $3 \mathrm{mg} / \mathrm{kg} /$ day after $\mathrm{E}_{2}$ withdrawal lowered $\mathrm{T}_{\text {skin }}$ similarly to $E_{2}$, and this effect was set within 2 days of treatment. Substituting ERr 731 after $E_{2}$ withdrawal therefore helped maintain body temperature similarly to $\mathrm{E}_{2}$ alone, suggesting the usefulness of ERr 731 as an alternative approach to existing hormonal therapy in humans. The oral bioavailability of ERr 731 was further confirmed by measuring the plasma levels of its primary metabolite, rhapontigenin.

Because hot flushes correlate with spikes in the peripheral LH and GnRH released from the hypothalamus, they most likely represent a disorder of hypothalamic thermoregulation [19]. In order to substantiate the $\mathrm{T}_{\text {skin }}$ changes with the hypothalamic expression patterns of genes related to the ER $\alpha / \beta$ signaling and bioactive peptides, we performed a pharmacogenomics assessment of gene expression profiles in the hypothalamus of OVX rats treated with $E_{2}$ or ERr 731. We observed a prominent ER $\beta$ selectivity of ERr 731 in vivo, as the treatment was associated with the activation of ER $\beta$ target genes (Th, Igfbp5 and (dh1), and had little effect on the ER $\alpha$-specific expression profiles. The ER $\beta$ specificity was further confirmed in reporter assays, as ERr 731 and rhapontigenin (an active metabolite of rhaponticin) acted as the full agonist of the ER $\beta$ receptor. Both the extract and the pure compound were highly selective for $E R \beta$, compared to $E_{2}$ and other estrogenic 
compounds, such as genistein and equol. These results were consistent with a previous study, where the total ERr 731 extract, as well as its individual compounds, have been demonstrated to act as potent, selective ER $\beta$ agonists in human endometrial cells, without affecting ER $\alpha$-meditated activities [9]. While no changes in the expression levels of the hypothalamic neurotrophic factors were observed in the ERr 731-treated animals, ERr 731 (but not $E_{2}$ ) treatment had a moderate suppressive effect on the mRNA levels of the agouti-related peptide Agrp. This might explain the small but significant reduction in body weight and fat mass associated with the administration of $1 \mathrm{mg} / \mathrm{kg} /$ day ERr 731, but the effect was not dose-dependent. AgRP is a crucial part of the melanocortin system involved in the regulation of food intake and energy balance through antagonistic effects on the melanocortin 3 and 4 receptors that stimulate a long-lasting increase in food intake [28]. Other botanical interventions, for example steroidal glycosides from milkweeds, were also shown to modulate AgRP levels in vivo [29].

In summary, this study validated the OVX/Tskin rat model as a suitable screening platform to evaluate the effects of dietary and botanical interventions on the mechanisms and treatments of menopause. Our experimental findings provided further evidence for the efficacy of ERr 731 in alleviating vasomotor menopausal symptoms, and raised the intriguing possibility of its effectiveness in improving wellbeing during the menopausal transition. Substituting ERr 731 after E2 withdrawal helped maintain body temperature similarly to $E_{2}$ alone, suggesting the usefulness of ERr 731 supplementation after the termination of HRT if these findings are confirmed in the future clinical studies.

\section{Materials and Methods}

\subsection{Chemicals}

The ERr 731 botanical extract from the Siberian rhubarb, also known as rhapontic rhubarb (Rheum rhaponticum L., family Polygonaceae), was manufactured by ChemischPharmazeutische Fabrik Göppingen Carl Müller Apotheker GmbH \& Co. (Göppingen, Germany) (Figure 1), and kindly provided by Metagenics Inc. (Gig Harbor, WA, USA). Rhapontigenin, (S)-equol and genistein were purchased from Cayman Chemicals (Ann Arbor, MI, USA). All other chemical reagents including $17 \beta$-estradiol $\left(\mathrm{E}_{2}\right)$ and solvents (analytical grade) were purchased from Sigma (St Louis, MO, USA).

\subsection{Monitoring of Tail Skin Temperature $T_{\text {skin }}$}

To record $\mathrm{T}_{\text {skin, }}$ SubCue Mini data loggers (Canadian Analytical Technologies, Calgary, $\mathrm{AB}$, Canada) were inserted into a protective covering (University Research Instrumentation Center, University of Arizona, Tucson, AZ, USA) as described previously [17] with the following modification: the length of the covering was extended by $5 \mathrm{~mm}$ to provide additional protection for data loggers against accidental nibbling. The assembled data loggers were attached on the ventral surface of the tail using double-sided tape. The data loggers were calibrated and set to record temperature every $15 \mathrm{~min}$ for the duration of the study. Mean $\mathrm{T}_{\text {skin }}$ values were calculated separately for the dark (active) and light (non-active) phases of the day cycle. All animal experiments were performed according to procedures approved by the NC Research Campus Institutional Animal Care and Use Committee in the David H. Murdock Research Institute, the AAALAC accredited animal care facility, and followed NIH guidelines.

\subsection{Animal Study 1: Model Validation}

Sham-operated and bilaterally ovariectomized female Sprague Dawley rats (10-weekold, 200-250 g, Charles River Laboratories, Wilmington, MA, USA) were housed 2 per cage in a temperature- $\left(21-23^{\circ} \mathrm{C}\right)$ and humidity-controlled environment under an inverted $12 \mathrm{~h}$ light cycle (lights on at $1900 \mathrm{~h}$ ). Rats were fed an AIN-93 standard diet (Research Diets, New Brunswick, NJ, USA) and tap water ad libitum. The experimental groups $(n=6)$ consisted of (1) sham-operated controls gavaged daily with $1 \mathrm{~mL}$ of inactive vehicle (10\% DMSO in saline), (2) OVX controls gavaged daily with the vehicle, (3) OVX, gavaged 
daily with $0.1 \mathrm{mg} / \mathrm{kg} /$ day $E_{2}$ suspension in vehicle, and (4) OVX, gavaged daily with $1 \mathrm{mg} / \mathrm{kg} /$ day ERr 731 suspension in vehicle. $T_{\text {skin }}$ temperature recordings were obtained daily for the duration of the study. On day 8, the animals were fasted overnight, sacrificed, and a terminal blood sample was collected via cardiac puncture.

\subsection{Animal Study 2: Dose Response}

The experimental groups $(n=6)$ consisted of (1) OVX controls gavaged daily with vehicle (10\% DMSO in saline); (2) OVX, gavaged daily with $0.1 \mathrm{mg} / \mathrm{kg} /$ day $\mathrm{E}_{2}$ suspension in vehicle; (3-5) OVX, gavaged daily with either $0.3,1.0$, or $3.0 \mathrm{mg} / \mathrm{kg} /$ day $\mathrm{ERr} 731$ suspension in vehicle. $T_{\text {skin }}$ temperature recordings were obtained during the $12 \mathrm{~h}$ dark (active) phase of the light cycle on days 2, 7 and 14 of the study. On day 16, animals were subject to body composition measurements by quantitative magnetic resonance using EchoMRI (Echo Medical Systems, Houston, TX, USA). Unanesthetized rats were placed in plastic restrainer tubes, and triplicate measurements were completed in less than $5 \mathrm{~min}$. Next, animals were fasted overnight, sacrificed on day 17 , and a terminal blood sample was collected via cardiac puncture. Terminal body weights, organ weights, and tissues samples were taken at each scheduled sacrifice. Tissues and serum were stored at $-80^{\circ} \mathrm{C}$ until molecular assays were performed. This study was also repeated once with similar results (not shown).

\subsection{Animal Study 3: Replacement Therapy}

All experimental groups $(n=6)$ were subjected to the treatment period set at 21 days and divided in three 7-day periods: days 1-7 (initial period, all animals received daily gavage with vehicle $10 \%$ DMSO in saline); days $8-14\left(E_{2}\right.$ supplementation period, all animals except OVX controls received daily gavage with $0.3 \mathrm{mg} / \mathrm{kg} / \mathrm{d} \mathrm{E}_{2}$ suspension in vehicle); and days 15-21 (replacement therapy period, $\mathrm{E}_{2}$ animals were further randomized into three groups and continued to receive either $0.3 \mathrm{mg} / \mathrm{kg} / \mathrm{d} \mathrm{E}$ or $1-3 \mathrm{mg} / \mathrm{kg} /$ day ERr 731 suspension in vehicle as a replacement treatment).

\subsection{Quantification of Plasma Rhaponticin}

Rhaponticin was measured in OVX rat plasma collected from animal studies 2 and 3. In both experiments, the last dosing was performed $1 \mathrm{~h}$ prior to animal sacrifice and plasma collection [30]. The presence of rhaponticin in plasma was detected by the fluorescent quenching method in the presence of $10 \mu \mathrm{M}$ cerium nitrate probe ( $\mathrm{pH} 7.4)$, as described previously [31].

\subsection{Gene Expression Studies}

Gene expression profiles for $\mathrm{ER} \alpha / \beta$ target genes [32] as well as neurotrophic factors $(B d n f, G d n f)$ and satiety peptides (Npy, Agrp, Cart, Pomc) [29] were measured by real-time quantitative PCR (qPCR) in hypothalamus brain tissues collected from animal study 2 . The total RNA was isolated using TRIzol reagent (Life Technologies, Carlsbad, CA, USA). RNA was quantified using the SynergyH1/Take 3 spectrophotometer (BioTek, Winooski, VT, USA). The cDNAs were synthesized using $2 \mu \mathrm{g}$ of RNA for each sample using a highcapacity cDNA Reverse Transcription kit on the ABI GeneAMP 9700 (Life Technologies).

The resulting cDNAs were amplified by qPCR using SYBR green PCR Master Mix (Life Technologies). To avoid interference due to genomic DNA contamination, only intronoverlapping primers were selected using the Primer Express version 2.0 software (Applied Biosystems, Foster City, CA, USA). qPCRs were performed on an ABI 7500 Fast (Life Technologies) using 1 cycle at $50^{\circ} \mathrm{C}$ for $2 \mathrm{~min}$ and 1 cycle of $95{ }^{\circ} \mathrm{C}$ for $10 \mathrm{~min}$, followed by 40 cycles of $15 \mathrm{~s}$ at $95^{\circ} \mathrm{C}$ and $1 \mathrm{~min}$ at $60^{\circ} \mathrm{C}$. The dissociation curve was completed with 1 cycle of $1 \mathrm{~min}$ at $95^{\circ} \mathrm{C}, 30 \mathrm{~s}$ at $55^{\circ} \mathrm{C}$, and $30 \mathrm{~s}$ at $95^{\circ} \mathrm{C}$. mRNA expression was analyzed using the $2^{-\Delta \Delta \mathrm{CT}}$ method [20] and normalized with respect to the expression of the gapdh housekeeping genes using 7500 Fast System SDS Software v1.3.0 (Life Technolo- 
gies). The amplification of specific transcripts was further confirmed by obtaining melting curve profiles.

\subsection{Estrogen Receptor Activity}

$\mathrm{ER} \alpha / \mathrm{ER} \beta$ receptor assays were performed by Indigo Biosciences (College Park, PA, USA). The ER $\alpha / E R \beta$ reporter vectors used in these studies comprised the firefly luciferase gene functionally linked to the appropriate upstream ER response element. Cells were treated in triplicates with various concentrations of test articles, including ERr 731 $(0.023-50 \mu \mathrm{g} / \mathrm{mL})$, rhapontigenin $(0.01-100 \mu \mathrm{M})$, quercetin $(0.023-50 \mu \mathrm{g} / \mathrm{mL})$, genistein $(0.001-100 \mu \mathrm{M})$ and $(\mathrm{S})$-equol $(0.00001-100 \mu \mathrm{M}) . \mathrm{E}_{2}$ was used as positive control and DMSO $(0.1 \%)$ was used as a solvent control. Cells were incubated for $24 \mathrm{~h}$ and average relative light unit (RLU) values were used to determine $E R \alpha$ and $E R \beta$ activity.

\subsection{Statistics}

Data were analyzed by one-way ANOVA followed by Dunnett's multiple-range tests using Prism 6.0 (GraphPad Software, San Diego, CA, USA). All data were presented as means \pm SEM. Significant differences were accepted when the $p$-value was $<0.05$.

Author Contributions: S.K. conceived the study and outlined the scope of work. M.W. performed animal work, K.H. performed RNA extractions and qPCRs, and T.R. performed the analytical chemistry analysis of the botanical extract and its components. V.K. obtained data on estrogen receptor activity. S.K., T.R. and M.W. drafted the manuscript, A.D. and V.K. edited the manuscript. All authors have read and agreed to the published version of the manuscript.

Funding: This work was supported in part by Metagenics grant 2014-0284 (SK).

Institutional Review Board Statement: The study was conducted according to the NIH guidelines, and approved by the NC Research Campus Institutional Animal Care and Use Committee (protocol 13-009).

Informed Consent Statement: Not applicable.

Data Availability Statement: The data presented in this study are available on request from the corresponding author.

Acknowledgments: We thank Peter W. Heger for his critical review of the manuscript.

Conflicts of Interest: S.K. received research grants from Metagenics. A.D. and V.K. were employed by Metagenics. M.W., K.H., and T.R. declare no conflict of interest. The funders had no role in the design of the study; in the collection, analyses, or interpretation of data with the exception of estrogen receptor activity; in the writing of the manuscript; or in the decision to publish the results.

$\begin{array}{ll}\text { Abbreviations } \\ \mathrm{E}_{2} & \text { 17 } \beta \text {-estradiol } \\ \mathrm{ERr} 731 & \text { Siberian rhubarb Rheum rhaponticum } \text { L. root extract } \\ \mathrm{ER} \alpha / \beta & \text { Estrogen receptor } \alpha / \beta \\ \mathrm{HRT} & \text { Hormone replacement therapy } \\ \mathrm{OVX} & \text { Ovariectomized } \\ \mathrm{T}_{\text {skin }} & \text { Skin temperature }\end{array}$

\section{References}

1. Shapiro, M. Menopause Practice. Can. Fam. Physician 2012, 58, 989.

2. Van Dijk, G.M.; Kavousi, M.; Troup, J.; Franco, O.H. Health Issues for Menopausal Women: The Top 11 Conditions Have Common Solutions. Maturitas 2015, 80, 24-30. [CrossRef] [PubMed]

3. Sassarini, J.; Lumsden, M.A. Oestrogen Replacement in Postmenopausal Women. Age Ageing 2015, 44, 551-558. [CrossRef]

4. Nelson, H.D.; Vesco, K.K.; Haney, E.; Fu, R.; Nedrow, A.; Miller, J.; Nicolaidis, C.; Walker, M.; Humphrey, L. Nonhormonal Therapies for Menopausal Hot Flashes: Systematic Review and Meta-Analysis. JAMA 2006, 295, 2057-2071. [CrossRef] [PubMed]

5. Geller, S.E.; Studee, L. Botanical and Dietary Supplements for Menopausal Symptoms: What Works, What Does Not. J. Womens Health 2005, 14, 634-649. [CrossRef] 
6. Cvoro, A.; Paruthiyil, S.; Jones, J.O.; Tzagarakis-Foster, C.; Clegg, N.J.; Tatomer, D.; Medina, R.T.; Tagliaferri, M.; Schaufele, F.; Scanlan, T.S.; et al. Selective Activation of Estrogen Receptor-Beta Transcriptional Pathways by an Herbal Extract. Endocrinology 2007, 148, 538-547. [CrossRef]

7. Heger, M.; Ventskovskiy, B.M.; Borzenko, I.; Kneis, K.C.; Rettenberger, R.; Kaszkin-Bettag, M.; Heger, P.W. Efficacy and Safety of a Special Extract of Rheum rhaponticum (ERr 731) in Perimenopausal Women with Climacteric Complaints: A 12-Week Randomized, Double-Blind, Placebo-Controlled Trial. Menopause 2006, 13, 744-759. [CrossRef]

8. Kaszkin-Bettag, M.; Ventskovskiy, B.M.; Kravchenko, A.; Rettenberger, R.; Richardson, A.; Heger, P.W.; Heger, M. The Special Extract ERr 731 of the Roots of Rheum rhaponticum Decreases Anxiety and Improves Health State and General Well-Being in Perimenopausal Women. Menopause 2007, 14, 270-283. [CrossRef]

9. Wober, J.; Möller, F.; Richter, T.; Unger, C.; Weigt, C.; Jandausch, A.; Zierau, O.; Rettenberger, R.; Kaszkin-Bettag, M.; Vollmer, G. Activation of Estrogen Receptor-Beta by a Special Extract of Rheum rhaponticum (ERr 731), Its Aglycones and Structurally Related Compounds. J. Steroid Biochem. Mol. Biol. 2007, 107, 191-201. [CrossRef]

10. Papke, A.; Kretzschmar, G.; Zierau, O.; Kaszkin-Bettag, M.; Vollmer, G. Effects of the Special Extract ERr $731^{\circledR}$ from Rheum rhaponticum on Estrogen-Regulated Targets in the Uterotrophy Model of Ovariectomized Rats. J. Steroid Biochem. Mol. Biol. 2009, 117, 176-184. [CrossRef]

11. Kaszkin-Bettag, M.; Richardson, A.; Rettenberger, R.; Heger, P.W. Long-Term Toxicity Studies in Dogs Support the Safety of the Special Extract ERr 731 from the Roots of Rheum rhaponticum. Food Chem. Toxicol. Int. J. Publ. Br. Ind. Biol. Res. Assoc. 2008, 46, 1608-1618. [CrossRef] [PubMed]

12. Hasper, I.; Ventskovskiy, B.M.; Rettenberger, R.; Heger, P.W.; Riley, D.S.; Kaszkin-Bettag, M. Long-Term Efficacy and Safety of the Special Extract ERr 731 of Rheum rhaponticum in Perimenopausal Women with Menopausal Symptoms. Menopause 2009, 16, 117-131. [CrossRef] [PubMed]

13. Kaszkin-Bettag, M.; Beck, S.; Richardson, A.; Heger, P.W.; Beer, A.-M. Efficacy of the Special Extract ERr 731 from Rhapontic Rhubarb for Menopausal Complaints: A 6-Month Open Observational Study. Altern. Ther. Health Med. 2008, 14, 32-38. [PubMed]

14. Kaszkin-Bettag, M.; Ventskovskiy, B.M.; Solskyy, S.; Beck, S.; Hasper, I.; Kravchenko, A.; Rettenberger, R.; Richardson, A.; Heger, P.W. Confirmation of the Efficacy of ERr 731 in Perimenopausal Women with Menopausal Symptoms. Altern. Ther. Health Med. 2009, 15, 24-34.

15. Chang, J.-L.; Montalto, M.B.; Heger, P.W.; Thiemann, E.; Rettenberger, R.; Wacker, J. Rheum rhaponticum Extract (ERr 731): Postmarketing Data on Safety Surveillance and Consumer Complaints. Integr. Med. Encinitas Calif. 2016, 15, 34-39.

16. Romanovsky, A.A.; Ivanov, A.I.; Shimansky, Y.P. Selected Contribution: Ambient Temperature for Experiments in Rats: A New Method for Determining the Zone of Thermal Neutrality. J. Appl. Physiol. 2002, 92, 2667-2679. [CrossRef]

17. Williams, H.; Dacks, P.A.; Rance, N.E. An Improved Method for Recording Tail Skin Temperature in the Rat Reveals Changes during the Estrous Cycle and Effects of Ovarian Steroids. Endocrinology 2010, 151, 5389-5394. [CrossRef]

18. Dacks, P.A.; Rance, N.E. Effects of Estradiol on the Thermoneutral Zone and Core Temperature in Ovariectomized Rats. Endocrinology 2010, 151, 1187-1193. [CrossRef]

19. Casper, R.F.; Yen, S.S. Neuroendocrinology of Menopausal Flushes: An Hypothesis of Flush Mechanism. Clin. Endocrinol. 1985, 22, 293-312. [CrossRef]

20. Winer, J.; Jung, C.K.S.; Shackel, I.; Williams, P.M. Development and Validation of Real-Time Quantitative Reverse TranscriptasePolymerase Chain Reaction for Monitoring Gene Expression in Cardiac Myocytesin Vitro. Anal. Biochem. 1999, $270,41-49$. [CrossRef]

21. Richardson, D.; Shepherd, S.; Tyra, J. Age-Related Potentiation of the Cutaneous Capillary Blood Flow Response to Heat Stress. Microcirc. Endothelium. Lymph. 1991, 7, 305-323.

22. Thompson, G.E.; Stevenson, J.A. A Sex Difference in the Temperature Response of Rats To Exercise. Can. J. Physiol. Pharmacol. 1965, 43, 437-443. [CrossRef] [PubMed]

23. Kobayashi, T.; Tamura, M.; Hayashi, M.; Katsuura, Y.; Tanabe, H.; Ohta, T.; Komoriya, K. Elevation of Tail Skin Temperature in Ovariectomized Rats in Relation to Menopausal Hot Flushes. Am. J. Physiol. Regul. Integr. Comp. Physiol. 2000, 278, R863-R869. [CrossRef] [PubMed]

24. Reagan-Shaw, S.; Nihal, M.; Ahmad, N. Dose Translation from Animal to Human Studies Revisited. FASEB J. Off. Publ. Fed. Am. Soc. Exp. Biol. 2008, 22, 659-661. [CrossRef] [PubMed]

25. Teekachunhatean, S.; Mattawanon, N.; Khunamornpong, S. Short-Term Isoflavone Intervention in the Treatment of Severe Vasomotor Symptoms after Surgical Menopause: A Case Report and Literature Review. Case Rep. Obstet. Gynecol. 2015, 2015. [CrossRef]

26. Ghazanfarpour, M.; Sadeghi, R.; Roudsari, R.L.; Najmabadi, K.M.; Bazaz, M.M.; Abdolahian, S.; Khadivzadeh, T. Effects of Red Clover on Hot Flash and Circulating Hormone Concentrations in Menopausal Women: A Systematic Review and Meta-Analysis. Avicenna J. Phytomed. 2015, 5, 498-511.

27. Borrelli, F.; Ernst, E. Black Cohosh (Cimicifuga racemosa) for Menopausal Symptoms: A Systematic Review of Its Efficacy. Pharmacol. Res. 2008, 58, 8-14. [CrossRef]

28. Cone, R.D.; Cowley, M.A.; Butler, A.A.; Fan, W.; Marks, D.L.; Low, M.J. The Arcuate Nucleus as a Conduit for Diverse Signals Relevant to Energy Homeostasis. Int. J. Obes. Relat. Metab. Disord. J. Int. Assoc. Study Obes. 2001, 25 (Suppl. 5), S63-S67. [CrossRef] 
29. Komarnytsky, S.; Esposito, D.; Rathinasabapathy, T.; Poulev, A.; Raskin, I. Effects of Pregnane Glycosides on Food Intake Depend on Stimulation of the Melanocortin Pathway and BDNF in an Animal Model. J. Agric. Food Chem. 2013, 61, 1841-1849. [CrossRef]

30. Esposito, D.; Komarnytsky, S.; Shapses, S.; Raskin, I. Anabolic Effect of Plant Brassinosteroid. FASEB J. 2011, 25, 3708-3719. [CrossRef]

31. Sun, Y.; Zhao, Y.; Yang, X. A Simple and Rapid Spectrofluorimetric Method for Determining the Pharmacokinetics and Metabolism of Rhaponticin in Rat Plasma, Feces and Urine Using a Cerium Probe. Lumin. J. Biol. Chem. Lumin. 2013, 28, 523-529. [CrossRef] [PubMed]

32. Shanle, E.K.; Zhao, Z.; Hawse, J.; Wisinski, K.; Keles, S.; Yuan, M.; Xu, W. Research Resource: Global Identification of Estrogen Receptor $\beta$ Target Genes in Triple Negative Breast Cancer Cells. Mol. Endocrinol. 2013, 27, 1762-1775. [CrossRef] [PubMed] 